\title{
PROSA, RUANG, DAN KOTA PASCAKOLONIAL
}

\author{
Moh. Atikurrahman \\ Sastra Indonesia Universitas Airlangga \\ Email: atiqurrahmann@gmail.com
}

\begin{abstract}
Abstrak
Sampai saat ini kajian mengenai ruang kota pascakolonial dalam kaitannya dengan prosa-prosa Indonesia modern dapat dikatakan minim. Di lain pihak, sejarah sastra kita dilimpahi penulis-penulis seperti Armijn Pane, Idrus, Pramoedya Ananta Toer, Iwan Simatupang, Budi Darma dst., yang secara konsisten menulis prosa-prosanya dengan latar kota-kota bekas jajahan. Sayangnya, keberadaan karyakarya mereka belum diimbangi dengan kajian-kajian yang memadai mengenai perjumpaan antara penulis prosa kita dengan kota sebagai representasi dari sebuah pengalaman pascakolonial. Tulisan ini berusaha untuk melacak hubungan integral antara penulis prosa modern Indonesia dan kota dengan menggunakan pendekatan teori ruang spasial dalam kaitannya dengan kajian sastra pascakolonial di Indonesia. Pendekatannya menggunakan teori spasial Sara Upstone, khususnya mengenai ruang (spatial) kota.
\end{abstract}

Kata kunci: ruang, kota, pascakolonial.

Abstract

Today, the studies on post-colonial urban space in relation with Indonesian modern prose can be said to be minimal. On the other hand, in the history of Indonesian literature, we are endowed with writers like Armijn Pane, Idrus, Pramoedya Ananta Toer, Iwan Simatupang, Budi Darma etc., who consistently write prose with the background of the ex-colonial towns. Unfortunately, there is no enough studies of the encounter between those writers with the city as a representation of a post-colonial experience. This paper tried to track the integral relationship between Indonesian modern prose writers to the city by using the spatial space theory in relation to the study of post-colonial literature in Indonesia. This analysis used the spatial theory by Sara Upstone as the approach, especially regarding to space (spatial) city.

Keywords: spatial, city, postcolonial.

\section{Pendahuluan}

Munculnya kota pertama dalam sejarah umat manusia terjadi di lembah Sungai Nil dan Efrat-Tigris. Pada masa itu, kedua tempat tersebut memiliki ketercukupan bahan pangan yang dihasilkan oleh pedesaan, sehingga terdapat orang-orang yang terbebaskan dari pekerjaan mengolah tanah. Mereka yang tinggal di kedua kota ini mencukupi kebutuhan hidupnya dengan mengembangkan suatu mata pencaharian baru, yakni perdagangan dan transfortasi, dan bukan lagi dari sektor pertanian (Budianto, 2001: 108).

Dalam buku TownsandCities, Jones (dalam Budianto, 2001) menulis bahwa keberadaan kota menunjukkan apa yang disebut The Hight of Man's Achievement. Sebuah kota selalu berkait erat dengan peradaban (civilization) yang mencerminkan kemenangan manusia atas alam, sebab mereka tidak lagi bergantung sepenuhnya pada pengolahan alam (tanah). Sebaliknya, penghuni kawasan luar kota dipandang serba kurang beradab dan disebut sebagai barbar. Di kotalah berkembang apa yang disebut sebagai kebudayaan umat manusia. Hal ini tampak pada tingginya keterampilan teknis, berkembangnya gagasan manusia, distribusikannya wacanawacana, majunya berbagai bidang kesenian, dan munculnya segala penemuan baru.

Sejak kelahiran hingga tumbuhkembangnya kesusastraan Indonesia modern dapat dikatakan sebagai sastra kota. Ismail Husein (dalam Malna, 2000:308-309) menyebutkan, sastra Indonesia dapat dicirikan sebagai sastra kota karena bahasa sastranya adalah bahasa Melayu yang kemudian menjelma menjadi bahasa Indonesia dan banyak dipakai di kota-kota besar. Selain alasan tersebut, tumbuhnya elit baru melalui pendidikan dan 
organisasi-organisasi sosial-politik seperti partai bersamaan dengan tumbuhnya gerakan nasionalisme, perdagangan dan industri, yang kesemuanya berkembang di kota-kota besar. Faruk (2007:213) mengatakan, persentuhan masyarakat Indonesia dengan sastra modern tidak hanya melalui institusi pendidikan dan penerbit pemerintah, dalam hal ini Balai Pustaka. Transaksi ekonomi, politik, dan kemasyarakatan antara kolonialis Belanda dengan masyarakat Indonesia merupakan situs-situs awal dan penting dari terjadinya persentuhan kultural tersebut.

Setelah melalui berbagai proses negosiasi ekonomi dan politik, pertempuran, penaklukan, dan korban-korban yang besar, kolonialis Belanda berangsur-angsur berhasil menaklukkan Ambon, Sulawesi Selatan, Jawa, dan akhirnya seluruh wilayah Indonesia. Akhirnya terbentuk apa yang disebut sebagai masyarakat kolonial Belanda di Indonesia. Wilayah-wilayah yang menjadi pusat pemukiman orang-orang Belanda di Indonesia, misalnya Jakarta dan Surabaya, dengan segera menjadi kota-kota besar yang berfungsi sebagai pusat-pusat kekuasaan, perekonomian, dan kebudayaan, sehingga tidak hanya memancing proses urbanisasi masyarakat Indonesia menuju ke kota-kota tersebut, melainkan juga mendorong terjadinya usaha-usaha peniruan dan adaptasi mereka terhadap gaya hidup dan kebudayaan modern Eropa (Faruk, 2007: 213).

Sejak kolonialisasi awal mereka di Indonesia, orang-orang Belanda telah membawa serta kebudayaan, kesenian, dan kesusastraan mereka. Kebudayaan kolonialis Belanda itulah yang kemudian dijadikan model bagi gagasan mengenai modernitas. Berkenaan dengan kesusastraan, Faruk (1995:142) dalam tulisan lain menyatakan bahwa salah satu faktor yang dianggap ikut andil dalam menentukan perkembangan itu adalah kontak sastra Indonesia dengan karya-karya dan pahampaham kesusastraan yang ada di luar Indonesia. Peniruan dan adaptasi oleh para elit pribumi modern awal terhadap model kesusastraan Eropa itu hanya dimungkinkan terjadi dalam geografi bernama kota. Dengan demikian, tidak mengherankan apabila kemudian kesusastraan Indonesia tumbuh-berkembang sebagai sastra kota. Terhadap kondisi tersebut, Afrizal Malna (2000: 309) mengatakan, sastra Indonesia yang tumbuh sebagai "sastra kota" lebih merupakan konsekuensi politik dan linguistik dari proses bentukan nasionalisme sastra yang kemudian dilembagakan sebagai kesusastraan Indonesia modern.

Apa yang disebut sebagai sastra kota dalam tulisan ini adalah karya-karya sastra yang merepresentasikan perjumpaan para penulis prosa dengan kota, sehingga dalam karya-karya mereka tersebut terjelma apa yang disebut sebagai pengalaman pasca-kolonial. Kalau merujuk pada sejarah resmi kesusastraan Indonesia, maka perjumpaan para prosais kita dengan kota telah dimulai sejak era Balai Pustaka. Namun, pada masa itu intensitas perjumpaan antara keduanya masih relatif minim, bahkan mendua, kota dan desa, atau bahkan dapat dikatakan lebih berat pada aspek yang terakhir. Dalam karya-karya seperti Sitti Nurbaya, Tenggelamnya Kapal Van Der Wijk, Salah Asuban dst., dapat ditemukan gerak-laku tokohtokohnya di antara kota dan desa. Namun, secara keseluruhan karya-karya tersebut masih dipenuhi dengan romantisme lewat penjabaran panorama pedesaan yang dominan dalam narasinya. Dengan demikian, dapat dikatakan bahwa pada masa itu perjumpaan para prosais dengan kota masih kabur.

Intensitas perjumpaan antara prosais dengan kota yang dominan terjadi pada masa berikutnya, yakni Pujangga Baru. Armijn Pane melalui Belenggu dapat dikatakan sebagai tonggak, dan merupakan contoh yang apik mengenai keterkaitan antara seorang prosais dengan kota. Berlainan dengan corak karyakarya para penulis sebelumnya, dalam Belenggu Armijn Pane bercerita mengenai tokoh-tokoh yang memiliki keterkaitan yang intim dengan latar kejadiannya, sebuah kota. Berbeda dengan karya-karya Balai Pustaka yang cenderung bercerita secara ideal, Belenggu berpretensi untuk bercerita mengenai dunia yang lebih nyata dan 
kacau dalam gerak-laku antar tokoh-tokohnya.

Idrus, berturut kemudian Pramoedya Ananta Toer, Iwan Simatupang, Budi Darma, bahkan Afrizal Malna dan Sony Karsono merupakan segelintir barisan prosais yang intens menceritakan perjumpaan mereka sebagai prosais dengan kota-kota yang mereka diami. Demi kepentingan kajian ini, penulis akan melacak hubungan yang kompleks antara para prosais modern kita dengan kota berdasarkan objek material cerpen Tunggu Aku Di Simpang jalan Itu karya Iwan Simatpang dan Novel Rafilus karya Budi Darma. Penulis hendak mengetahui bagaimana representasi keterkaitan antara para penulis prosa Indonesia modern dengan kotakota pascakolonial.

\section{Ruang Kota Pascakolonial}

Teori yang digunakan dalam kajian ini adalah ruang kota pascakolonial oleh Sara Upstone. Berkenaan dengan kajian pascakolonial, Upstone dalam Spatial Politics in the Postcolonial Novel menekankan pada politik ruang, suatu wilayah yang pernah ditempati dan dikontrol oleh kolonial, dan kolonial telah meninggalkan wilayah tersebut. Bagi Upstone daerah-daerah bekas jajahan dianggap masih memiliki ruang-ruang kolonial yang ditinggalkan pada wilayah jajahan itu, meskipun secara fisik kolonial sudah tidak bercokol lagi pada ruang terjajah. Ruang-ruang tersebut oleh Upstone distratifikasikan dalam bangsa (nation), perjalanan (journey), kota (city), rumah (bome) dan tubuh (body). Pada setiap level ruang tersebut terdapat unsur politik yang diungkap (Suciawati, 2014: 17).

Dalam telaahnya terhadap novel-novel pascakolonial, Upstone menguraikan bahwa ' $a$ reading of the postcolonial politics novel that is centered upon an alternative concept of spatial politics: one that is rooted not solely in a politics of the nation, but instead reflects the diverse spaces that construct the postcolonial experience' (2009: 1). Pengalaman kolonial yang dimaksud di sini adalah pengalaman yang terjadi pada daerah yang pernah diduduki atau mengalami kolonialisme Barat. $\mathrm{Hal}$ ini berkaitan dengan konsep kolonialisme tentang penguasaan teritori. Berkaitan dengan pengertian kolonialisme sebagai penguasaan teritori, maka penguasa kolonial ingin menanamkan kekuasan dan melestarikannya dengan berbagai strategi. Strategi penting yang digunakan adalah melakukan kontrol terhadap wilayah kekuasaan serta masyarakatnya. Upaya kontrol itu dimanfaatkan untuk mewujudkan dan melanggengkan wilayah teritori jajahannya, baik pada tingkat bangsa, ruang publik seperti kota, bahkan sampai ke ruang-ruang domestik seperti tempat tinggal dan ruang-ruang pribadi (seperti individu).

Dalam Oxford English Dictionary, diksi 'koloni' diperikan sebagai 'not only a community of settlers, but also 'the territory' occupied by that community'. Berdasarkan pengertian tersebut, Upstone yakin bahwa strategi kontol berkaitan erat dengan konsep batas-wilayah tertentu merupakan batas teritori yang digunakan pihak kolonial untuk menguasai koloninya. Dalam praktiknya, penerapan pemetaan dilakukan dengan rigid dan pasti guna melanggengkan kekuasaan kolonial. Konsep ruang berbatas ini ditanamkan pada masyarakat sebagai sesuatu yang tetap, terkontrol, absolut, dan natural. Dengan adanya konsep batas yang tampak absolut, tidak dapat digoyahkan oleh kelompokkelompok lokal, wilayah teritori dengan batasbatasnya menjadi sesuatu yang keberadaannya sah (legitimate entuty), dan statusnya yang absolut menghancurkan berbagai prefensi dari masyarakat sebelumnya, serta praktik kesukuan yang telah ada (Upstone, 2009: 4-5; dalam Suwiwati, 2009: 18). Konsep tentang batas yang ditanamkan pada masyarakat dan memiliki tujuan untuk kontrol, mempertahankan stabilitas, serta menghindarkan berbagai resistensi, terjaga dengan adanya penerimaan dan persetujuan masyarakat bahwa batas bersifat alamiah. Dengan demikian, seolah-olah masyarakat tidak menyadari adanya konstruksi kolonial tentang batas tersebut. Kondisi inilah yang menjadikan masyarakat homogen sehingga mudah dikontrol.

Upstone (dalam Suciati, 2014: 19) berpendapat bahwa dalam pandangan 
pascakolonial ruang disadari lebih bersifat cair, berbeda dengan harmonisasi dan idealisasi ala kolonial. Oleh karena itulah ia kemudian menawarkan gagasan bahwa penulis-penulis pascakolonial menciptakan ruang sebagai tempat berbagai kemungkinan dan resistensi, dengan merebut kembali kecairan ruang yang telah ditolak oleh konsep kolonial dalam gagasan ruang berbatasnya dan dengan memberikan lokasi fungsi-fungsi politis. Hal ini berarti bahwa penulis pascakolonial ingin mengungkapkan chaos yang ada, dan membuka peluang untuk perlawanan atau resistensi terhadap konstruksi kolonial.

Dikatakan pula bahwa pandangan ruang pascakolonial menolak konstruksi teritori, memberi penawaran bahwa ruang seharusnya direklamasi, suatu pandangan yang pada awalnya mengandung berbagai perbedaan dan melihat ruang di luar pemikiran kolonial, dimana ruang menjadi lokasi, bukan sebagai negasi atas apa yang telah berlalu melainkan negosiasi (Upstone, 2009:13). Berbeda dengan pandangan kolonial, pandangan pascakolonial melihat ruang berisi suara-suara heterogen yang memiliki berbagai pengalaman yang memberi penekanan pada perbedaan dan subjektifitas (Upstone, 2009:13). Suara-suara heterogen dan pengalaman inilah yang memunculkan chaos. Penyikapan chaos tersebut tidak untuk menghilangkan semua stabilitas yang ada, melainkan lebih pada upaya pemanfaatannya dalam membongkar pandangan yang dianggap tetap dan menanamkan pola-pola pemahaman dan pengalaman-pengalaman yang baru sehingga dibutuhkan fluiditas ruang yang tidak bisa didapatkan dalam konsep kolonial maupun tradisi, atau pula dari konsep Barat dan Timur yang sudah dibatasi-batasi tersebut. Hal ini, pada akhirnya, memunculkan post-space. Menurut Upstone (2009:15) post-space merupakan konsep yang berada di luar batas-batas kolonial maupun batas-batas tradisi, bahkan melampaui dan berada sebelum batas-batas tersebut muncul; ia juga bisa dikatakan suatu ruang yang hibrid, cair dan bergerak, sehingga tidak memiliki batas-batas lagi. Dalam teritori yang lebih kecil, ruang kota (bagi kepentingan kolonialisasi) merupakan salah satu konstruksi yang berperan untuk menjalankan fungsi politis dalam menegakkan nilai-nilai kolonial, dan peran ini ditampilkan melalui etalase pada sebuah kota.

Ruang kota berada dalam level ruang setelah ruang bangsa (nation) dan perjalanan (journey). Bagi Upstone (2009: 85) kota merupakan sebuah ruang yang identik dengan representasi yang secara metonimik merefleksikan ketegangan ruang nation yang sekaligus menawarkan sebuah gagasan geopolitik yang khas. Berkenaan dengan ruang kota, Upstone melihat keterkaitan yang erat dan kompleks antara para novelis dengan geograf itu dalam wujud bagaimana kota itu hadir (nyata) dan bagaimana kota itu dibayangkan. Terdapat beragam model kota yang disebut dalam bukunya, yaitu Utopian Cities, Desired City, Nowhere City, dan Carnival City.

\section{Utopian Cities}

Gagasan mengenai 'kota utopia' selalu berkait erat dengan 'utopia' dalam bahasa Yunani Kuno, 'not a place'. Bagi Upstone kota secara inhern selalu terikat dengan wacana utopia-terejawantahkan dalam ruang urban. Ruang-ruang urban ini dibayangkan bukan sebagaimana kota itu hadir (nyata), melainkan sebagai suatu mimpi atau impian. Lebih lanjut Upstone mengatakan, "Despite various representations of the horrors of the industrialised city, the city has also been at the same time a space of projection: of personal desires and communal hopes." (2009:85).

Bagi Upstone wacana utopia sangat relevan untuk melacak bagaimana para novelis pascakolonial menafsirkan ruang urban kota. Upstone mengatakan, "As the colonist justifies imperial seizure of territory in ideal terms of adventure and freedom so the city-utopia is often the focus for similar yearnings. In both cases these ideals are in stark. contrast to lived reality. As colonial space overwrites the freedom necessary for territorial expansion with ordering and division, so the utopian city succumbs to similiar processes" (2009: 85-86). 
Bagi Upstone sendiri, para penulis pascakolinial terlibat dalam gagasan mengenai ihwal yang ideal mengenai kota. Dia berujar, "This connection between colonial cities and the utopian ideal city presents oppurtinies to explore how postcolonial novelists engage with urban space of idealised desire to investigate whether the the relationship between colonial nation and postcolony is replicated on urban scale" (2009:87).

Representasi yang dihadirkan Budi Darma sebagaimana tampak dalam novelnya, Rafilus, menunjukkan corak sebagaimana disebutkan Upstone di atas. Dengan kata lain, novel Budi Darma tersebut menggambarkan bagaimana si penulis novel terlibat secara langsung dengan gagasan mengenai sebuah kota yang ideal. Dalam Rafilus, banyak ditemui penyebutan nama-nama jalan, seperti Jl. Raya Darmo, Jl. Dr. Soetomo, Jl. Diponegoro, Jl. Panghela, Jl. Bronggalan, Jl. Tambangboyo, Jl. Pandegeling, Jl. Ambengan, Jl. Perak, Jl. Tunjungan, dst. Untuk pembaca Surabaya atau mereka yang mengetahui seluk-beluk kota ini, penyebutan nama-nama jalan tersebut memiliki konteks tertentu.

Sarkawi B. Husein sejarawan dari Universitas Airlangga dalam bukunya, Negara Di Tengah Kota: Politik Representasi dan Simbolisme Perkotaan (Surabaya 1930-1960), menguraikan bahwa penamaan jalan-jalan di kota itu selalu terikat dengan simbol kekuasaan. Ia memaparkan bahwa nama-nama jalan itu menunjukkan bagaimana simbol-simbol di Kota Surabaya, khususnya nama jalan itu, merefleksikan keseimbangan kekuasaan, dan bagaimana dinamika kekuasaan membawa perubahan pada sebuah simbol sebagaimana dijelaskan berikut.

"Pola jalan dalam kota Surabaya sampai tahun 1900-an dapat dikelompokkan ke dalam dua pola. Pertama, pola jalan yang tidak direncanakan dan timbul sebagai akibat kegiatan ekonomi serta hubungan sosial pendudukanya. Jika di sebelah barat Jembatan Merah dihuni oleh orang-orang Eropa, maka di sebelah timurnya dihuni oleh orang-orang Cina serta orang-orang
Melayu dan Arab. Jalan-jalan utama di pemukiman ini adalah Handelstraat, Chinesevoorstraat, Chineshe Breestraat, Chinesche Buitenweg, Chinesche Heerenstraat, Chinesche Tempelstraat, dan lain-lain. Adapun jalan-jalan di daerah pemukiman orang Arab dan Melayu antara lain Kampemenstraat, Ampel ,dan sekitarnya.

Pola yang kedua adalah yang terletak di daerah bagian selatan kota yang merupakan daerah perumahan dan pemukiman baru. Jaringan jalan di kawasan ini sengaja direncanakan untuk keperluan perumahan orang-orang Eropa. Nama-nama Belanda terletak di perumahan-perumahan Eropa, kawasan pelabuhan, serta daerah perdagangan. Jalan-jalan yang berada di kawasan elit Darmo misalnya, diberi nama yang merujuk nama para gubernur jenderal Belanda yang pernah memerintah di Indonesia, seperti Altingstraat, Baudstraat, van den Boschlaan, Coen Boulevard, van Heutzstraat, van Hoogendorplaan dsb. Meskipun di kawasan ini memakai nama Belanda, Jalan Raya Darmo yang merupakan jalan utama dan strategis tidak mengalami pergantian, tetapi hanya ditambah menjadi Darmo Boulevard.

Atas nama nasionalisme dan penghargaan atas jasa pahlawan, maka nama-nama jalan setempat yang sudah lama melekat dalam memori masyarakat harus diganti dengan nama-nama pahlawan yang justru tidak dikenal masyarakat. Altingstraat diubah menjadi Jalan Trunojoyo, Bothstraat menjadi Jalan Dr. Wahidin, Carpentierstraat menjadi Jalan Untung Suropati, Coen Boulevard menjadi Jalan Dr. Soetomo, Daendelstraat diubah menjadi Jalan Imam Bonjol, van Heutzstraat diganti dengan nama musuhnya Jalan Teuku Umar" (Husein, 2010:85).

\section{Dalam bab Sepanjang Jalan Kenangan:} Makna dan Perebutan Simbol Nama Jalan Di Kota Surabaya, Sarkawi secara khusus memberi ulasan yang cukup rigid mengenai sejarah jalanjalan di Kota Surabaya. Nama sebuah jalan dapat berganti nama lain tergantung siapa yang berkuasa, baik Belanda hingga pada era kemerdekaan. Khusus mengenai pendudukan 
Jepang yang secara resmi menduduki Surabaya pada 8 Maret 1942, tidak ada perubahan terhadap nama-nama jalan sekalipun jalan itu menggunakan nama Belanda. Di samping singkatnya periode pendudukan mereka, demi kelangsungan kekuasannya, Jepang lebih tertarik memobilisasi massa dengan cara kekerasan atau cara yang lebih simpatik. Untuk menghapus memori kolonialisasi Belanda, Jepang merusak situs-situs seperti patung-patung dan tugutugu peninggalan Belanda. Selama periode pendudukannya, Jepang hanya mengubah sebuah nama jalan, yakni Jalan Prambanan menjadi Jalan Kempetai (2010: 87-88).

Dalam kesimpulannya, Sarkawi menuliskan bahwa klasifikasi nama jalan menunjukkan adanya kebijakan segresi etnik dan status sosial masyarakat. Jalan yang menggunakan nama-nama Belanda misalnya dipergunakan untuk kawasan elite yang dihuni oleh orang-orang Belanda, sedangkan nama jalan Cina dipakai untuk kawasan perdagangan yang memang banyak dihuni oleh orang-orang Tionghoa. Untuk kawasan yang dihuni oleh penduduk pribumi, nama-nama jalannya banyak memakai nama-nama tumbuhan, hewan, dan nama-nama lokal lainnya. Ketika Indonesia merdeka, kecenderungan segresi di atas tampaknya tidak bergeser. Nama-nama jalan di kawasan elite yang dahulunya menggunakan nama-nama Belanda diganti dengan nama-nama Indonesia yang juga elite (baca: pahlawan), sedangkan di kawasan Pecinan diubah dengan nama komoditi perdagangan seperti Jl. Kopi, Jl. Karet, dan lain-lain.

Dalam novel Rafilus pada bagian 3 (khususnya 3.2 dan 3.3) terdapat sub-judul Van der Klooning dan Jaan Van Kraal yang secara tak langsung membenarkan pernyataan Sarkawi di atas dan sekaligus menunjukkan bagaimana penulis novel ini terlibat secara aktif dalam persentuhannya dengan kota yang ideal tersebut.

"Pada tahun-tahun lima puluhan, orangorang Belanda di Surabaya sudah merasa tidak tentram. Saya yakin di kota-kota lain lain mereka juga demikian. Mereka masih ingin menganggap Indonesia surga dunia, namun Pemerintah Belanda sudah kehabisan gigi. Mau tidak mau tidak mugkin lagi mereka berlagak seperti penjajah. Indonesia sudah merdeka. Mareka hanyalah orang asing di negeri asing...

Jumlah orang Belanda pada waktu itu masih sangat besar. Mereka tinggal di daerah-daerah terhormat, antara lain di Jl. Raya Darmo. Tentu saja mereka tidak tinggal di gang-gang dan kampung-kampung... Tapi ingat, tidak semua orang Belanda banar-benar Belanda. Kulit mereka tidak putih, tapi hitam. Sementara itu, rambut mereka kebanyakan tidak tidur dan tidak pula tegak. Mereka menganggap diri mereka benar-benar Belanda dan meminta hak untuk diperlakukan sebagai Belanda tulen... Menjelang berakhirnya masa penjajahan Belanda, jumlah mereka membunting. Mungkin mereka nampak lebih banyak karena Belanda yang benar-benar Belanda sudah melesat, dan menghirup udara negerinya sendiri. Begitu Belanda-Belanda putih meninggalkan Surabaya, mereka yang sebenarnya bukan Belanda ini beramairamai masuk ke bekas rumah Belanda putih. Sebelum mereka melahap kesempatan ini, sebetulnya mereka sudah tinggal di daerah-daerah terhormat, tetapi bukan kelas satu. Andaikata dulu mereka tinggal di kampung-kampung, tidak mungkin mereka mendapat perlakuan sebagai orang Belanda. Tidak mungkin Pemerintah Belanda memberi kesamaan derajat kepada BelandaBelanda hitam ini, andaikata mereka menjadi koki, kuli, atau jongos. Dan koki, kuli, serta jongos tidak mungkin tidak tinggal di kampung" (Darma, 2008: 38).

Narasi di atas mengungkapkan banyak hal terkait kota bernama Surabaya. Lewat narasi seorang opas pos bernama Munandir yang bercerita tentang pengalamannya pada masa silam (sekitar tahun 50-an), tampak bagaimana etalase kota hadir dan dibayangkan dengan latar masa peralihan. Di situ juga tampak bagaimana terdapat sekat-sekat ruang yang sengaja dibangun oleh kolonial untuk membedakan 
antara kelas atas, menengah, dan bawah. Sekat itu hadir bersinergi dengan nama-nama jalan. Seperti diungkap Sarkawi di atas, keberadaanya merupakan segresi etnik dan status sosial.

Sejarah kolonialisasi Kota Surabaya cukup panjang. Pendudukan kolonial Belanda terhadap Surabaya berlangsung selama kuranglebih 200-an tahun. Sepanjang pendudukan itu Surabaya disulap sedemikian rupa. Berkenaan dengan tata ruang, apa yang diterima sebagai Surabaya hari ini tak lebih dari Surabaya sebagaimana dibayangkan kolonial. Dalam novel Rafilus, banyak ruang-ruang kota Surabaya yang disebutkan di dalamnya. Namun, secara khusus kawasan elite Darmo diceritakan dengan cukup panjang-lebar (dua sub-bab).

Seperti diceritakan novel tersebut, terdapat dua orang "Belanda-Belanda hitam" bernama Van der Kooning dan Jaan Van Kraal yang tinggal di kawasan elite Darmo. Seperti disebutkan di atas, pada masa kolonial kawasan ini merupakan kawasan elite tempat tinggal tentara Belanda. Kedua orang "BelandaBelanda hitam" ini digambarkan melalui tokoh Munandirkepada tokoh 'saya' sebagaisosokyang kabur. Dalam bercerita, Munandir cenderung memberikan deskripsi-deskripsi panjang lebar, dengan nada yang khusus, sinis namun juga was-was. Sehingga, melalui pembayangan tokoh opas pos itu, dapat dipahami bagaimana penulis hendak menembus kecairan ruang dan menciptakan ruang kemungkinan resistensi. Dengan menggambarkan Darmo sebagai kawasan elite yang angkuh dan tak ramah bagi seorang opas pos semacam Munandir, penulis bergerak dalam merebut kembali kecairan ruang yang telah ditolak oleh konsep kolonial dalam gagasan ruang berbatasnya dan dengan memberikan lokasi fungsi-fungsi politis.

Ketika Munandir, misalnya, melintasi Jalan Darmo di depan rumah bernomor 54, dia dihinggapi halusinasi-halusinasi yang membayangkan keberjarakannya dengan ruang tersebut beserta penghuninya. Hal ini dapat dilihat dari kutipan berikut.
"Demikianlah, saya terus mengontel sepeda tanpa lelah. Sebentar lagi saya akan melewati rumah besar di Jl. Raya Darmo no. 54. Setiap kali melewati rumah itu, saya tertarik untuk menengok patung manusia di pekarangan rumah. Saya berhenti, kemudian memandang patung itu. Patung itu terbuat dari besi, dan sangat kokoh. Sinar lampu kedua trem itu membuat patung nampak berkilat-kilat. Pikiran saya mau tidak mau meloncat kembali ke Van der Klooning. Sekarang patung itu sudah tidak ada. Mungkin orang Belanda yang tinggal di situ sudah memboyongnya ke Negeri Belanda. Saya masih ingat benar, betapa jahanamnya Belanda itu. Namanya Jaan van Kraal. Sekarang rumah itu menjadi Markas Komando Pemulihan dan Penertiban Keamanan Wilayah Indonesia Timur" (Darma, 2008: 48).

Dari tingkah-polah Munandir saat melintasi Jalan Raya Darmo, jelas tampak adanya konsep batas yang tampak absolut, tidak dapat digoyahkan oleh kelompokkelompok lokal. Seperti disebut Upstone (2009: 4-5) teritori tersebut hadir dengan batasbatas yang menjadikannya sebuah keberadaan yang sah (legitimate entuty), dan statusnya yang absolut menghancurkan berbagai prefensi dari masyarakat sebelumnya, serta praktik kesukuan yang telah ada. Kawasan bernama Darmo telah tertanam dalam masyarakat dan mengontrol mereka. Dalam masa 200-an tahun, kolonial Belanda telah mempertahankan stabilitas, serta menghindarkan berbagai resistensi, disemai dengan adanya penerimaan dan persetujuan masyarakat bahwa batas bersifat alamiah. Ketika Munandir hanya mampu terheran-heran menyaksikan patung besi di pekarangan rumah itu, seolah-olah dia tidak menyadari adanya konstruksi kolonial tentang batas tersebut.

Pada alinea berikutnya diceritakan Munandir berhenti di depan rumah besar milik Jaan van Kraal.

"Saya bergerak lagi, kemudian berhenti tepat di depan rumah Jaan van Kraal. Kemudian saya mengambil batu besar. Dengan sangat berhati-hati saya 
membidik patung. Setelah bidikan saya tepat, saya lemparkan batu itu kuatkuat. Patung itu penjelmaan Van der Klooning. Saya menghajarnya.... Batu menggampar patung, menciptakan bunyi kelontang sangat keras. Dengan cepat anjing-anjing herder di dalam rumah menyalak ganas. Saya cepat-cepat naik sepeda, kemudian menggenjotnya lebih cepat daripada kilat. Anjing-anjing herder di dalam rumah menyalak makin ganas. Saya mengayuh terus, tanpa sempat menoleh" (Darma, 2008: 49).

Adegan ini memberi penyataan kepada kita bahwa penulis pascakolonial hendak mengungkapkan chaos dan membuka peluang untuk melakukan perlawanan atau resistensi terhadap konstruksi kolonial. Meskipun dengan menanggung konsekuensi bahwa dia berpotensi menjadi mangsa anjing-anjing herder dalam rumah Jaan van Kraal.

Cerita Munandir kepada 'saya' tentang pengalamannya pada masa silam dapat dilihat sebagai ihwal yang mengikat representasi penulis novel kota. Dalam hal ini, gambaran Munandir mengenai kawasan elit Darmo beserta penghuninya sebagai kawasan yang tidak ramah, tak lebih merupakan pandangan individu pascakolonial yang terkonstruksi sejak masa kolonial. Bahwa hal itu diceritakan oleh Munandir sebagai kenangan atau masa silam, hal tersebut mengukuhkan konstruksi kota bernama Surabaya saat ini tak pernah terpisahkan dari masa lalunya.

Cerpen "Tunggu Aku di Pojok Jalan Itu" karya Iwan Simatupang dapat dibaca sebagai sebuah representasi penulis prosa mengenai perjumpaannya dengan ruang kota, dalam hal ini sebuah sudut kota bernama 'pojok jalan'. Cerpen ini bercerita tentang sepasang suamiistri, yang entah bagaimana muasalnya, suami berkata pada istrinya, "Tunggu aku di pojok jalan itu". Kalimat pembuka cerpen itu begitu lugas. Mengapa suami menyuruh istri menunggu di pojok jalan itu? Dikatakan selanjutnya, "Aku beli rokok dulu ke warung sana."

Dalam alinea selanjutnya disebutkan suami pergi ke warung untuk mencari rokok seperti dikatakannya. Namun sejak kepergiannya, istrinya tidak pernah melihatnya lagi. Baru sepuluh tahun berselang, suami kembali. Istrinya masih menunggu di pojok jalan itu. Pada suatu sore, mereka bertemu di 'pojok jalan itu'. Istrinya menyapa terlebih dahulu, "Selamat sore" yang dibalas suaminya dengan teguran yang sama, "Selamat sore". Setelah teguran itu, istrinya tak hendak melanjutkan sapaannya, yang diam-diam justru diharapkan oleh suami.

Alih-alih melanjutkan sapaan tadi, istrinya justru berpaling ke arah laki-laki lain yang kebetulan lewat. Sekali lagi, istrinya menyapa laki-laki itu dengan teguran yang persis sama, "Selamat sore", ditambah muka manis sebagaimana ia tunjukkan kepada suaminya. Untuk beberapa saat suami menyaksikan; lakilaki yang baru datang itu menghampiri namun tanpa membalas teguran istrinya. Malah dengan genitnya, laki-laki tersebut menjentik pipi istrinya, bercakap barang sebentar, berpegangan tangan, sebelum akhirnya meninggalkan suaminya seorang diri di 'pojok jalan itu'.

Oleh karena tak mengerti betul dengan apa yang terjadi barusan, suaminya memburu istri dan laki-laki asing tersebut. Istrinya menoleh, sekali lagi menegur dengan "selamat sore". Namun dalam "selamat sore" kedua untuk suaminya ini, istri menggunakan intonasi yang sudah familiar bagi suami. Istrinya terusik. Akhirnya suami berhenti, dan kembali ke hotel setelah beberapa saat lamanya termangu 'di bawah lentera pojok jalan itu'.

Di hotel suaminya mandi dan istirahat. Sebelum memasuki kamar hotel, ia sempat berbasa-basi tentang beberapa hal dengan pemilik hotel, seorang janda gemuk berusia lebih dari lima puluh tahun, yang olehnya dianggap berlebihan dalam memperlakukan dirinya sebagai tamu hotel. Esoknya, dan kebetulan (atau mungkin memang disengaja) juga sore hari, suaminya kembali ke tempat kemarin, 'di pojok jalan itu'. Seperti halnya kemarin, istrinya telah berada di sana. Saat suami menghampiri, istrinya menyapanya lagi; "selamat sore", yang dijawab oleh suaminya dengan sapaan selamat sore juga. 
Kebetulan tidak ada orang lain selain mereka 'di pojok jalan itu'. Mereka akhirnya bercakap. Waktu itu, apa yang terjadi selama sepuluh tahun berusaha diurai. Mulai dari bagaimana keduanya menilai perubahan pada diri masing-masing, hingga banyak hal sentimental lainnya. Mereka menyudahi hal yang sentimental itu dengan berpelukan satu sama lain.

Sejurus kemudian, suami menggiring istrinya pergi dari 'pojok jalan itu'. Suaminya mengajak, "mari", namun dijawab istrinya, "ke mana?". Hal tersebut terjadi berulangkali. Sampai akhirnya, mereka pergi dari 'pojok jalan itu'. Di tengah perjalanan, istrinya tibatiba menghentikan langkah, "Tunggu dulu!" kata istrinya, "Tarifku dua ratus sampai tengah malam. Sampai pagi, dobel...." Sontak saja suaminya kaget. Benar-benar tidak terpikirkan, tidak juga terantisipasi. Lalu, esok harinya suami meninggalkan kota tersebut dengan menggunakan kereta pertama yang berangkat subuh. Mencari 'kota lain' sebagai tempat tinggalnya.

Cerita tersebut memusat pada peristiwa antara suami-istri. Dari sebuah 'pojokan jalan' suami-istri ini berpisah, sepuluh tahun kembali bertemu lalu berpisah lagi. Sebagian besar narasi menggarap peristiwa-peristiwa yang terjadi antara kedua tokoh utamanya. Sementara ruang, persoalan yang fokus dari tulisan ini seperti terabaikan begitu saja. Dalam narasi cerpen ia sekadar disebutkan 'pojok jalan itu', dan tak terjelaskan. Anonim, seperti menyarankan dirinya untuk tidak diperhatikan oleh pembacanya (Muhtarom, 2013).

Namun, pendekatan Upstone mengenai wacana pascakolonial terhadap prosa melalui pembacaannya atas keruangan tidak didasarkan dominasinya dalam narasi-narasinya. Yang fundamental dalam pendekatan ini justru penyikapan terhadap ruang yang mengungkung tokoh-tokoh di dalamnya. Seperti disebutkan sebelumnya, bahwa terdapat perbedaan mengenai pemahaman latar cerita yang fisikal dan konseptual. Dalam cerpen itu meskipun 'pojok jalan itu' tampak sebagai sampiran, ia tetap memiliki signifikasi dalam pemaknaan atas pengalaman sebagai prosa pascakolonial.

'Pojok Jalan Itu' adalah sesuatu yang subtansial pada cerpen ini dalam kaitannya dengan pembacaaan prosa pascakolonial. Suami menyuruh istrinya untuk menunggu di 'pojok jalan itu'. Istrinya menunggu. Dan dilihatnya, memang, sepuluh tahun berselang ia masih berdiri di situ, tetap menunggu, "setia". Sekilas seperti tak ada perbedaan antara suami dan istri mengenai dimensi 'pojok jalan itu'. Namun ketika istrinya berkata, sebelum diajak kencan suaminya, "Tarifku dua ratus sampai tengah malam. Sampai pagi, dobel....", maka gugurlah anggapan tersebut. Sebab bagi keduanya, apa yang dianggap sebagai 'pojok jalan itu' ternyata memiliki dimensi yang berbeda.

Suami menyuruh istrinya menunggu di pojok jalan itu. Ketika ia menyuruh istrinya berdiri di situ, yang tak ternyatakan oleh suami pada istrinya adalah: kamu (istri) menunggu. Di situ. Dipojokekan jalan itu. Kamu adalab istriku. Kamu harus setia. Dan berdiri di situ. Sedangkan apa yang disebut sebagai sepuluh tahun itu tidak berarti bagi suami. Dalam hal ini, suami menganggap 'pojok jalan itu' adalah sesuatu yang fisikal. Sebaliknya, bagi istri, apa yang dimaksudkan sebagai 'pojok jalan itu' berbeda dengan anggapan suaminya. Baginya 'pojok jalan itu' adalah sesuatu yang konseptual. Maka tidak mengheran jika kemudian ia meminta tarif untuk berkencan. Apa yang dimaksudkan sebagai menunggu dan kesetiaan dalam maksud suaminya adalah berbeda sama sekali dalam pengertian istrinya.

Chaos pun tak terhindarkan. Hal ini berawal dari pertemuan hari pertama, lalu disusul pada hari berikutnya, dan puncaknya adalah ketika istrinya berkata kepada suaminya tentang tarifnya. Apa yang dapat dimaknai dari perkataan istri tersebut adalah bahwa istri sedang melakukan suatu gerakan overwritting mengenai hubungan suami-istri. Bagi istri, hubungan antara seorang suami dengan istrinya tak sekadar hubungan emosional, tapi juga hubungan transaksional (tarifku sekian). Pikiran-pikiran istri mengenai hubungan 
suami-istri adalah wujud dari pikiran-pikiran yang materialistik. Jika dirunut kembali, pikiran-pikiran transaksional dan materialistik mengenai suatu hubungan suami-istri di sini tidaklah khas Timur tapi merupakan pikiranpikiran yang diwariskan secara turun-temurun semenjak zaman kolonial.

Pikiran-pikiran Timur mengenai sebuah hubungan suami-istri adalah dominan persoalan emosional. Hal yang menyangkut material adalah sampiran. Maka, ketika berbicara mengenai hubungan ini, istri cenderung dinaifkan; ia harus tunduk dan patuh, sementara suami harus selalu menang. Namun, dalam cerpen ini tidaklah demikian. Istri meminta ongkos dalam urusan senggama. Mungkin, selama ini suami selalu merasa superior. Ketika suami menyuruh begini, dia tunduk. Ketika suami meminta itu, dia harus mengabulkan. Oleh karenanya, memasang tarif untuk sekali kencan (tidak peduli dia adalah suaminya), tak lain pernyataan istri bahwa dia bisa hidup mandiri tanpa keberadaan seorang suami. Lebih jauh lagi, istri menunjukkan ada tindakan emansipasi. Istri ingin menunjukkan kodrat yang setara dengan suami.

Apa yang dapat disimpulkan dari perbedaan suami-istri mengenai dimensi latar (fisikal dan konseptual) adalah bahwa masingmasing mempengaruhi bagaimana tokohtokoh dalam cerpen itu bergerak. Suami memahami 'pojok jalan itu' sebagai fisikal, sehingga ketika istrinya meminta tarif padanya, istrinya telah melabrak sesuatu yang selama ini diyakininya mengenai hubungan suami-istri. Pandangan suami di sini mewakili bagaimana pandangan primordial seorang Timur, pribumi. Sebaliknya, istri dengan pandangannya tentang hubungan suami-istri tak cukup didasarkan atas keterikatan emosional adalah pribadi yang menyikapi 'pojok jalan itu' sebagai ruang yang tak terbatas. Di sini istri mewarisi pandanganpandangan khas kolonial mengenai hubungan suami-istri.

'Pojok jalan itu' adalah latar cerita di sebuah sudut kota entah dimana, tak terjelaskan. Dalam cerpen ini, kesadaran terhadap 'pojok jalan itu' sebagai sesuatu yang konseptual dimiliki si istri. 'Pojok jalan itu' adalah ruang terbuka dimana terjadi banyak perjumpaan dan perpisahan, sekaligus dipahami oleh istri secara kognitif. Hal tersebut membangun kesadaran pada istri untuk menentukan bagaimana model relasi yang harus ditunjukkan. Dengan kata lain, istri dikontruksi oleh ruang itu sendiri untuk menjalani takdirnya sebagai pelacur.

\section{Kesimpulan}

Novel Rafilus dan cerpen "Tunggu Aku di Pojok Jalan Itu" menunjukkan adanya keterikatan antara cerita tersebut dengan latar cerita kota yang mengiringinya. Keterikatan tersebut menunjukkan adanya representasi perjumpaan antara kedua pengarang tersebut dengan geografi bernama ruang kota sebagai sebuah pengalaman pascakolonial. Kota dalam imajinasi kedua prosais tersebut hadir sebagai sesuatu yang inhern, dan merefleksikan ketegangan dalam perjumpaan dengan ruangruang yang telah hadir sejak masa kolonialisasi. Ketegangan itu berupa sikap resistensi yang mengarah pada sebuah chaos. Sikap resistensi itu sengaja diambil disebabkan kehendak penulis untuk menciptakan post-space terhadap ruangruang warisan kolonial tersebut.

Dalam Rafilus, kota bernama Surabaya digambarkan sebagai kota yang masih identik dengan masa lalunya (baca: kolonial). Dari seorang opas pos Munandir yang bercerita tentang kawasan elite Darmo, Surabaya tampak sebagai teritori yang hadir dengan batasbatasnya yang menjadikan keberadaannya sah (legitimate entuty), dan statusnya yang absolut menghancurkan berbagai prefensi dari masyarakat sebelumnya. Kawasan elite bernama Darmo telah tertanam dalam benak seorang opas pos sebagai kawasan yang selalu mengingatkan pada masa lalunya, dan ia mengontrol Munandir tentang bagaimana seharusnya berlaku sebagai opas pos (orang kecil). Ketika Munandir terheran-heran pada patung besi di pekarangan rumah Jaan van Kraal, di situ tampak dia tidak menyadari adanya konstruksi kolonial tentang batas status dirinya 
dengan status penghuni rumah tersebut.

Cerpen "Tunggu Aku di Pojok Jalan Itu" tampil dengan cara yang sangat berbeda dibandingkan dengan novel Rafilus. Dengan tidak memberi informasi yang spesifik mengenai lokasi cerita, hanya 'pojok jalan', dengan sendirinya cerpen itu menyarankan bahwa ia dapat terjadi di kota mana saja. Cerpen ini hadir dengan keumumannya, sehingga ia dapat lebih leluasa mengolah persoalan apa yang hendak diungkapkan oleh ceritanya, dalam hal ini cerita berlatar kota. Dari keumumannya itu, cerpen ini memanfaatkan kecairan ruangan; mengungkapkan bahwa persoalan hubungan relasional antar suami-istri di kota-kota besar tidak hanya terjalin lewat hubungan emosional tetapi juga transaksional. Hal itu ditunjukkan oleh istri yang menjelma menjadi pelacur karena tiadanya ketercukupan sandang-pangan dan kebutuhan biologis yang seharusnya dipenuhi oleh suami.

\section{Daftar Pustaka}

Berger, Peter L. 1986. Revolusi Kapitalis. Jakarta: LP3ES.

Darma, Budi. 2008. Rafilus. Yogyakarta: Jalasutra.

Faruk. 2007. Belenggu Pasca-Kolonial: Hegemoni dan Resistensi dalam Sastra Indonesia. Yogyakarta: Pustaka Pelajar.

Faruk. 1995. Perlawanan Tak Kunjung Usai: Sastra, Politik, Dekonstruksi. Yogyakarta: Pustaka Pelajar.

Husein, Sarkawi B. 2010. Negara Di Tengah Kota: Politik Representasi dan Simbolisme Perkotaan (Surabaya 1930-1960). Jakarta: LIPI Press.

Koestoer, Raldi Hendro. 2001. Dimensi Keruangan Kota: Teori dan Kasus. Jakarta: UIPress.

Malna, Afrizal. 2000. Sesuatu Indonesia. Yogyakarta: Bentang.

Muhtarom, Imam. 2013. Kulminasi: Teks, Konteks, dan Kota. Yogyakarta: Kasim Press.

Simatupang, Iwan. 1982. Tegak Lurus Dengan Langit. Jakarta: Sinar Harapan.

Suciati, Endang. 2014. Ruang Pascakolonial
Dalam The God Of Small Things Karya Arundhati Roy. Yogyakarta: FIB UGM.

Upstone, Sara. Spatial Politics in The Postcolonial Novel. Surrey, UK: ASGATE. 